\title{
Mangrove growth rings: fact or fiction?
}

\author{
Elisabeth M. R. Robert • Nele Schmitz • \\ Judith Auma Okello · Ilse Boeren · Hans Beeckman • \\ Nico Koedam
}

Received: 12 November 2009/Revised: 9 August 2010/Accepted: 18 August 2010/Published online: 2 September 2010

(C) Springer-Verlag 2010

\begin{abstract}
The analysis of tree rings in the tropics is less straightforward than in temperate areas with a demarcated unfavourable winter season. But especially in mangroves, the highly dynamic intertidal environment and the overriding ecological drivers therein have been a reason for questioning the existence of growth rings. This study aimed at casting light on growth rings in mangroves. In six mangrove species growing in Gazi Bay, Kenya (Sonneratia
\end{abstract}

Communicated by A. Braeuning.

E. M. R. Robert and N. Schmitz contributed equally to this work.

E. M. R. Robert $(\bowtie) \cdot$ N. Schmitz $(\bowtie)$.

J. A. Okello · N. Koedam

Laboratory for Plant Biology and Nature Management (APNA),

Vrije Universiteit Brussel (VUB), Pleinlaan 2,

1050 Brussels, Belgium

e-mail: erobert@vub.ac.be

N. Schmitz

e-mail: nschmitz@vub.ac.be

E. M. R. Robert · N. Schmitz - J. A. Okello - H. Beeckman Laboratory for Wood Biology and Xylarium,

Royal Museum for Central Africa (RMCA),

Leuvensesteenweg 13, 3080 Tervuren, Belgium

J. A. Okello

Kenya Marine and Fisheries Research Institute (KMFRI), Headquarter and Mombasa Station, P.O. Box 81651080100 , Mombasa, Kenya

I. Boeren

Institute of Botany (210), University of Stuttgart-Hohenheim,

70593 Stuttgart, Germany

\section{Boeren}

Research Group Ecosystem Management,

Research Institute for Nature and Forests (INBO),

Kliniekstraat 25, 1070 Brussels, Belgium alba, Heritiera littoralis, Ceriops tagal, Bruguiera gymnorrhiza, Xylocarpus granatum and Lumnitzera racemosa), the occurrence of growth rings was examined. Growth rate of each species was determined based on a 1-year period using the cambial marking technique. The effect of climate was furthermore considered by comparing the results with a number of wood samples originating from contrasting climatic regions. We can conclude that for growth rings to appear in mangroves more than one condition has to be fulfilled, making general statements impossible and explaining the prevalent uncertainty. Climatic conditions that result in a range of soil water salinity experienced over the year are a prerequisite for the formation of growth rings. For species with an anatomy characterized by indistinct ring boundaries, this should be combined with a growth rate of at least $0.3 \mathrm{~mm} / \mathrm{year}$. The use of growth rings for age or growth rate determinations should thus be evaluated on a case by case basis.

Keywords Mangrove tree rings and growth rate .

Pinning method $\cdot$ Salinity $\cdot$ Inundation frequency $\cdot$ Kenya . Dendrochronology

\section{Introduction}

Because of the lush vegetation and the absence of clearly defined seasonality, prejudice against acceptance of formation of annual rings in tropical trees has existed for a long time (e.g. Jacoby 1989; Walter and Breckle 1999). From the beginning of the twentieth century, however, the existence of annual rings in tropical trees has been reported recurrently (Geiger 1915; Coster 1927; Coster 1928; Berlage 1931; Mariaux 1967a, b, 1969, 1981; Worbes and Junk 1989; Worbes et al. 1992, 2003; Worbes 1995; Trouet 
et al. 2001; Fichtler et al. 2003, 2004; Verheyden et al. 2004b, 2005; Brienen and Zuidema 2005; Roig et al. 2005; Schöngart et al. 2006). The base of tree ring formation is the reaction of woody plants to seasonally fluctuating growth conditions: the alternation of specific wood anatomical features. This variance can result from a cambial dormancy, but also from a change in growth rate. In the tropics (1) the variation in precipitation between a rainy and a dry season (Worbes 1997; Brienen and Zuidema 2005; Verheyden et al. 2005; Trouet et al. 2006; Schmitz et al. 2007) and (2) annually occurring floods of great river systems (Worbes 1985, 1997; Schöngart et al. 2004; 2005) can affect annual tree growth. However, we should not deny that the absence of annual and/or distinct rings remains a common problem in dendro(chrono)logical and ecological studies of tropical trees (e.g. Worbes 1990; Sass et al. 1995; Dunisch et al. 2002; Brienen and Zuidema 2005; Hancock et al. 2006).

Although studies on mangrove stem increment have been going on for almost a century (e.g. Baker 1915; Amobi 1974; Duke et al. 1981; Shiokura 1989; Aziz and Khan 2001; Verheyden et al. 2004b; Krauss et al. 2006, 2007; Rajkaran and Adams 2008; Schmitz et al. 2008) it has never been clear whether annual growth rings are present in mangrove tree species. While some studies mentioned the absence of growth rings in several species (Marco 1935; Van Vliet 1976; Sun and Suzuki 2000), others did find rings although margins were not necessarily distinct (Amobi 1974; Rao et al. 1987; Srivastava and Suzuki 2001). More recent studies reported annual growth rings in more than one species (Menezes et al. 2003; Verheyden et al. 2004a, b, 2005; Yu et al. 2004, 2007; Chowdhury et al. 2008). Not water availability but soil water salinity (Robert et al. 2009b) was assigned as the major seasonal variable causing wood anatomical changes and hence growth rings. This discovery opens up new vistas to the analysis of mangrove growth rings for tree age and growth rate estimations. In view of the carbon sequestration programmes being set up in the framework of the Kyoto protocol, these approximations are essential to come to reliable predictions (Nabuurs and Mohren 1995; Field 1998; Vieira et al. 2005; Manhas et al. 2006; Mattsson et al. 2009) and are currently not available. Insight into mangrove wood formation is also needed to optimize and to acquire a scientific basis for forest management and plantation activities.

In the present study we investigated the occurrence of growth rings in six mangrove species growing across the intertidal area of the Kenyan coast, including a limited number of Rhizophora congeners growing under different climate conditions. This allowed comparison of species within one climatic context as well as an intrageneric comparison over climate types. The aim of the study was to examine the growth rate of these mangrove species, as well as their wood anatomy for occurrence of putative growth rings in relation to climate and local site conditions (soil water salinity and inundation frequency). Making use of the cambial marking technique (Mariaux 1967a, b; Verheyden et al. 2004a; Schmitz et al. 2007, 2008) growth rate of the different species was measured from May 2005 to June 2006, and the number of growth rings formed within this year was counted. We wished to understand the causation of ring formation, but first addressed the actual presence of tree rings.

\section{Materials and methods}

\section{Study area}

The research was conducted in the mangrove forest of Gazi Bay $\left(4^{\circ} 25^{\prime} \mathrm{S}, 39^{\circ} 30^{\prime} \mathrm{E}\right)$ at the Kenyan coast (Fig. 1). The forest has a total area of about 600 ha (UNEP 2001; Neukermans et al. 2008). Sampling was done in five sites (site 1-5, Fig. 1) from the bay up into the creek and to the mouth of the Kidogoweni (Fig. 1), a seasonal river functioning as an important source of freshwater for the forest during the rainy season (Kitheka 1997). The climate along the Kenyan coast is characterized by a bimodal distribution of precipitation with a distinct dry season from December to March that is followed by a long and a short rainy season from April to July and from October to November, respectively (Fig. 2c). Mean annual temperature ranges from 22 to $30^{\circ} \mathrm{C}$, while mean relative humidity ranges from 65 to $81 \%$ (annual averages of minima and maxima from Mombasa for the period 1972-2001, data from the Kenyan Meterological Department, Mombasa, Kenya).

For each study site, soil water salinity and inundation class have been measured as described in Schmitz et al. 2008 and Robert et al. 2009a. Soil water salinity measurements were made with a hand-held refractometer (ATAGO, Tokyo, Japan) at approximately $25 \mathrm{~cm}$ depth. Inundation classes are according to Tomlinson (1994) where class I, II, III and IV correspond to areas inundated by $100-76,75-51,50-26$ and $25-5 \%$ of the high tides, respectively.

In addition to the sample set obtained by fieldwork, four stem discs of Rhizophora were selected from the Tervuren Xylarium to examine the presence of growth rings under different climatic and/or environmental conditions (Fig. 2). One disc was taken from Rhizophora apiculata from Galle, Sri Lanka (Tw57236) that experiences an equatorial climate (Peel et al. 2007), one from $R$. mucronata from Djibouti (Tw39263) with a warm desert climate (Peel et al. 2007) and two discs from $R$. mucronata from site 1 (Tw56729) and site 3 (Tw55886) in Kenya (Table 1; Fig. 1). 
Fig. 1 QuickBird satellite images of Gazi Bay acquired in 2002 (Neukermans et al. 2008) and map of east Africa situating Gazi Bay on the Kenyan east coast (black dot). The five study sites together with the genera from which stem discs have been taken are indicated (site 1-5). The Kidogeweni, a seasonal river that provide freshwater to the mangrove forest, is indicated on the top left satellite image. Adapted from Robert et al. 2009a

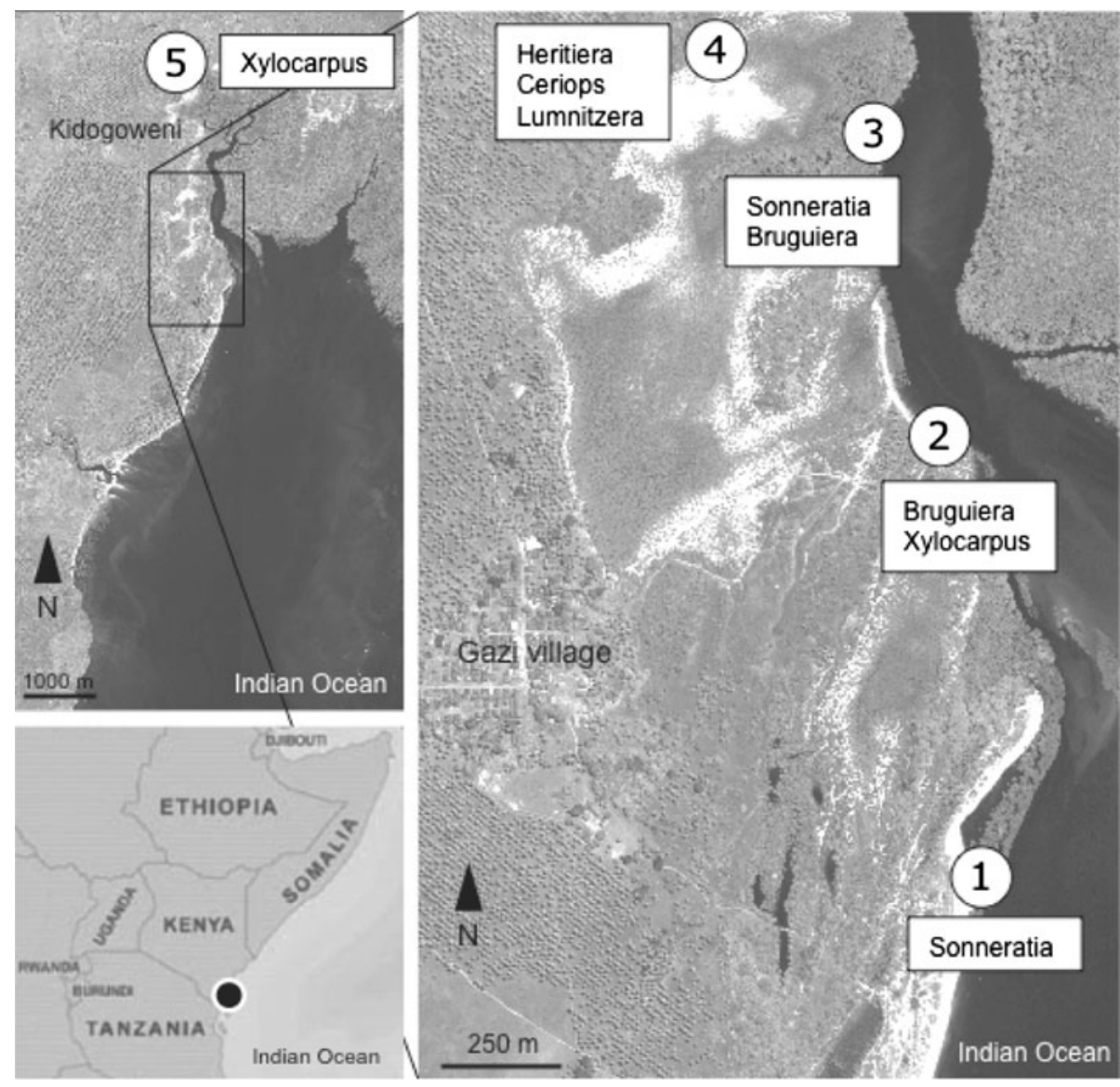

Cambial marking and wood analysis

Besides R. mucronata and Avicennia marina that have been analysed in previous studies by Verheyden et al. (2004b) and Schmitz et al. (2007, 2008), six other Kenyan mangrove species that occur widely in the forest of Gazi were investigated, i.e., Sonneratia alba, Heritiera littoralis, Ceriops tagal, Bruguiera gymnorrhiza, Xylocarpus granatum and Lumnitzera racemosa. Two to six moderately sized trees were randomly sampled (with the post-experiment felling in mind) from two study sites for each species. For C. tagal and L. racemosa all studied trees exceptionally originated from site 4 (Table 1; Fig. 1). The cambium of the mangrove trees was marked in May 2005 at $130 \mathrm{~cm}$ height using a hypodermic needle with a diameter of $1.2 \mathrm{~mm}$. Four additional C. tagal trees (Tw57794-97), of which the cambium was marked in October 1999 by Anouk Verheyden, were included in the study. Before felling in June 2006, tree height was determined trigonometrically and stem circumference at $130 \mathrm{~cm}$ height was measured from which stem diameter was derived. Temperature as well as rainfall of the years studied are within the normal range for the region (Lieth et al. 1999 and data from the Kenyan Meterological Department, Mombasa, Kenya).
All wood discs collected from the marked areas were air-dried and deposited in the wood collection of the Royal Museum of Central Africa in Tervuren, Belgium (Table 1). Sanded stem discs were analysed both macro- and microscopically in order to (1) describe the anatomy of the growth rings, (2) count the number of rings formed during the 1-year period between May 2005 and June 2006 and (3) measure the radial increment during this 1-year period using digital image analysis software (AnalySIS Pro version 3.2, Soft Imaging System GmbH, Münster, Germany). For the description of the ring boundary type (Table 2), the IAWA (International Association of Wood Anatomists) terminology (Wheeler et al. 1989) was followed. The radial increment was measured at $2 \mathrm{~mm}$ distance left and right from the needle incision point to avoid the influence of wound tissue that is formed as a response to wounding (Iqbal 1925). The change in wood anatomy near the wound indicated the position of the cambium at the time of the pinning.

\section{Data analysis}

Per species and study site, the mean of the radial increment measurements left and right of the cambial wound was 

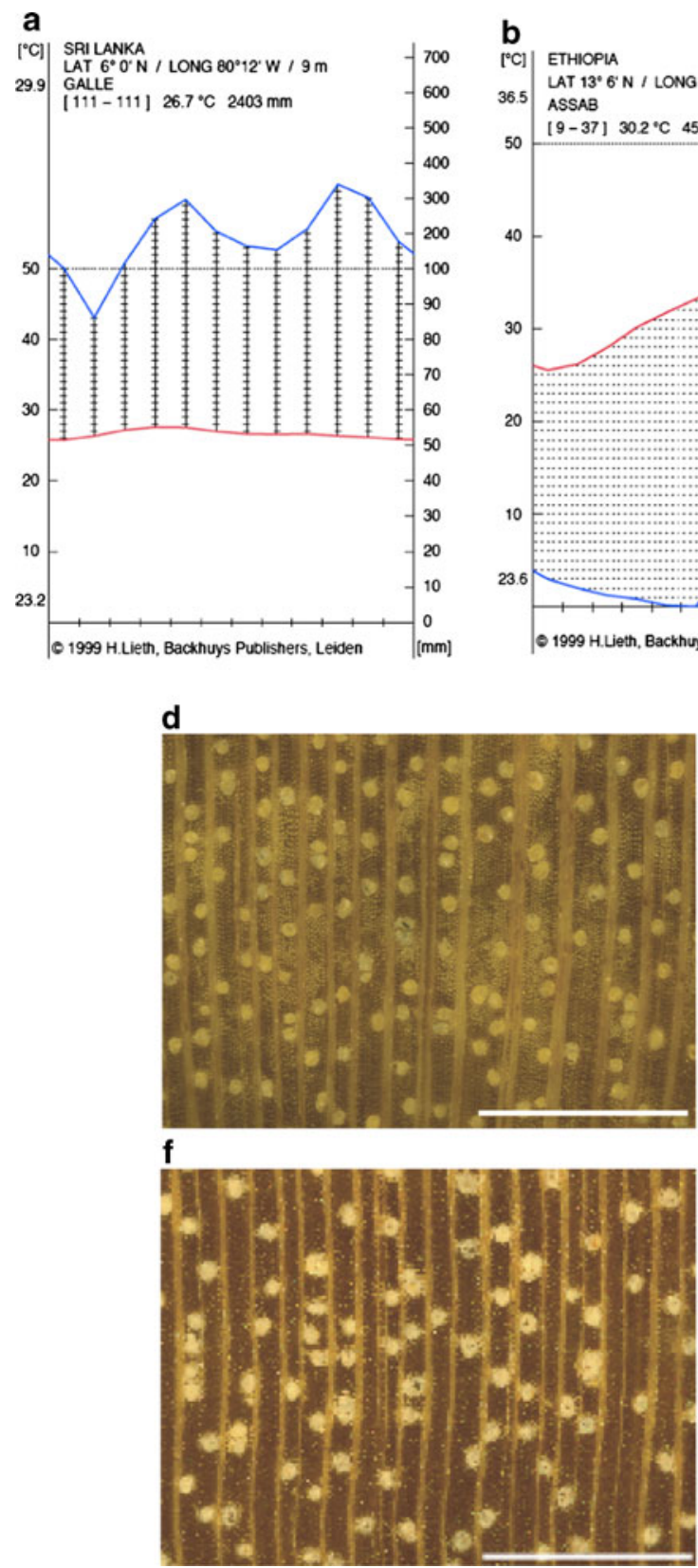

Fig. 2 Global distribution of mangroves implies growth under various climatic conditions $(\mathbf{a}-\mathbf{c})$ resulting in a wood anatomy showing growth rings more or less distinct $(\mathbf{d}-\mathbf{g})$. Also the internal dynamics of the mangrove environment play a major role as shown by the contrasting growth patterns at two Kenyan sites $(\mathbf{f}-\mathbf{g})$. Climate diagrams - July to June (Lieth et al. 1999) of a Galle, south west coast of Sri Lanka, b Assab, Ethiopia (nearest coastal station to Djibouti for

calculated per stem disc and converted to an annual radial increment from the exact period between pinning and felling date. Afterwards, means were calculated per species and study site. A one-way ANOVA was conducted in Statistica 7.0 (StatSoft Inc., Tulsa, USA) to test differences in annual radial increment between species.
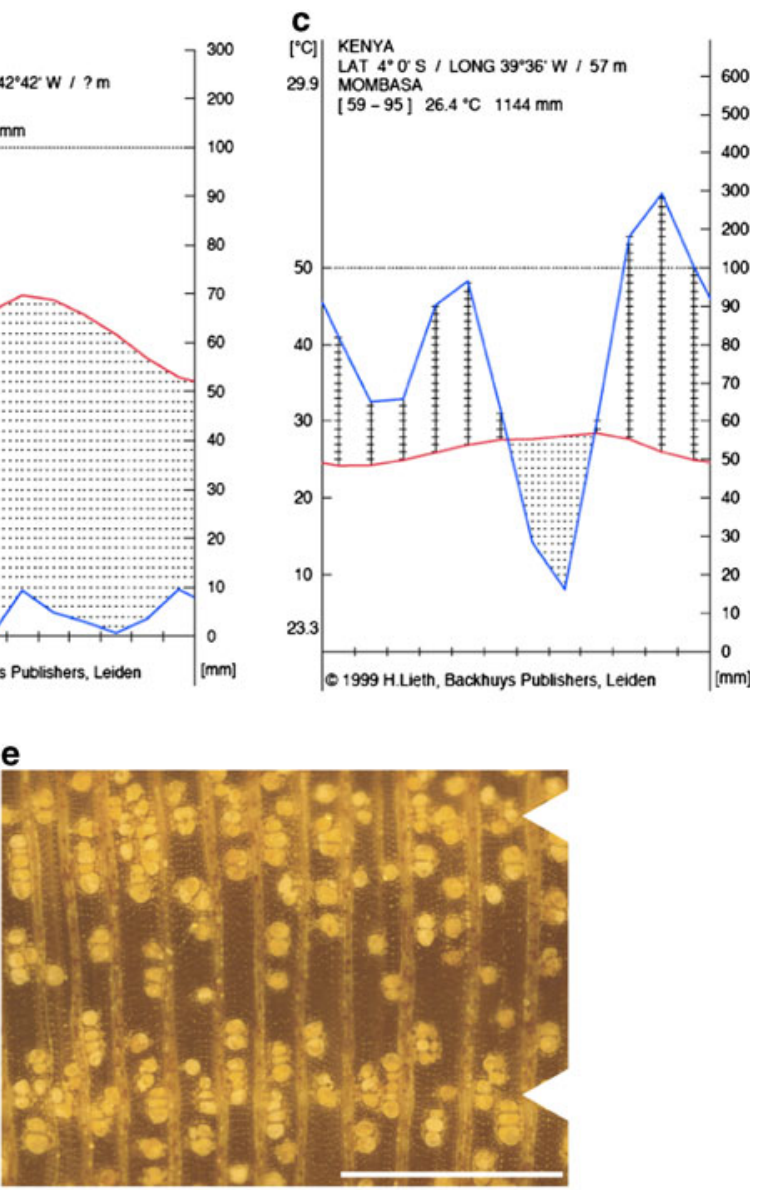

g

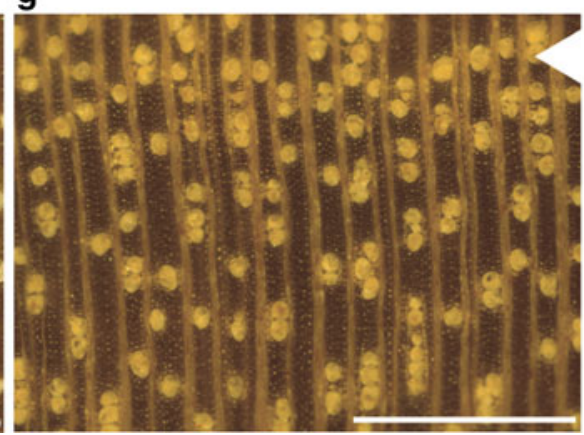

which a climate diagram was available) and $\mathbf{c}$ Mombasa, south east coast of Kenya. Pictures showing wood anatomy are from sanded discs of d Rhizophora apiculata, Galle (Sri Lanka), e Rhizophora mucronata, Djibouti and $\mathbf{f}-\mathbf{g} R$. muconata from Gazi Bay (Kenya), site 1 (g) and site 3 (f) (Fig. 1). Arrowheads mark ring boundaries. Scale bars are $1 \mathrm{~mm}$

\section{Results}

When comparing the wood anatomy and distinctness of growth rings in Rhizophora species growing under different climate types, clear differences were found. While $R$. mucronata from Djibouti showed quite distinct growth 
Table 1 Annual radial increment of the six mangrove species studied in a 1-year period between May 2005 and June 2006 together with the characteristics of study sites (soil water salinity and inundation class) and trees (tree height and stem diameter at $1.3 \mathrm{~m}$ )

\begin{tabular}{llllllll}
\hline Species & Specimen $^{\mathrm{a}}$ & $\begin{array}{l}\text { Study } \\
\text { site }\end{array}$ & $\begin{array}{l}\text { Soil water salinity: } \\
\text { min-max (range) }(\%)\end{array}$ & $\begin{array}{l}\text { Inund. } \\
\text { class }\end{array}$ & $\begin{array}{l}\text { Tree } \\
\text { height (m) }\end{array}$ & $\begin{array}{l}\text { Stem diameter } \\
\text { at 1.3 m (cm) }\end{array}$ & $\begin{array}{l}\text { Annual radial } \\
\text { increment (mm/years) }\end{array}$ \\
\hline Sonneratia alba & Tw58983,85,86 & 3 & $21-46(25)$ & I & $6.0 \pm 1$ & $4.7 \pm 0.7$ & $2.6 \pm 2$ \\
& Tw58981,82,84 & 1 & $25-36(11)$ & I & $6.0 \pm 2$ & $6.0 \pm 2$ & $1.8 \pm 0.5$ \\
Heritiera littoralis & Tw58978-80 & 4 & $10-90(80)$ & IV & $4.5 \pm 0.6$ & $6.0 \pm 2$ & - \\
& Tw58976,77 & 5 & $5-68(63)$ & III & $5.0 \pm 4$ & $5.0 \pm 3$ & - \\
Ceriops tagal & Tw58998,99 & 4 & $10-90(80)$ & IV & $2.6 \pm 0.4$ & $4.0 \pm 1$ & $0.28 \pm 0.09$ \\
Bruguiera gymnorrhiza & Tw58971,74,75 & 3 & $21-46(25)$ & I & $3.4 \pm 0.5$ & $3.0 \pm 1$ & $0.2 \pm 0.1$ \\
& Tw58970,72,73 & 2 & $25-36(11)$ & I & $3.8 \pm 0.7$ & $4.4 \pm 0.6$ & $0.9 \pm 0.5$ \\
Xylocarpus granatum & Tw58965-68 & 2 & $25-36(11)$ & I & $3.9 \pm 0.6$ & $5.0 \pm 0.8$ & $2.5 \pm 1$ \\
& Tw58963,64 & 5 & $0-11(11)$ & III & $7.0 \pm 1$ & $4.1 \pm 0.7$ & $2.3 \pm 1$ \\
Lumnitzera racemosa & Tw58995-97 & 4 & $10-90(80)$ & IV & $3.0 \pm 1$ & $4.0 \pm 1$ & $0.81 \pm 0.08$ \\
\hline
\end{tabular}

Soil water for salinity measurements was taken at about $25 \mathrm{~cm}$ depth. Inundation classes are according to Tomlinson (1994). Values for tree height, stem diameter and radial increment are means \pm standard deviation

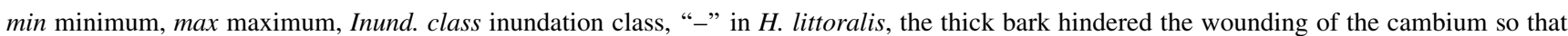
annual radial increment could not be measured

${ }^{a}$ Accession number of the Tervuren wood (Tw) collection

${ }^{\mathrm{b}}$ See Fig. 1

rings with striking changes in vessel density (Fig. 2e), no obvious variation in wood anatomy was seen in $R$. apiculata from Galle (Sri Lanka) (Fig. 2d) or in R. mucronata from site 3 in Gazi (Figs. 1 and 2f). Although faint, the $R$. mucronata sample from site 1 in Gazi did show a fluctuation in vessel density (Figs. 1 and $2 \mathrm{~g}$ ) that is at the base of the growth rings.

All six species macroscopically showed growth rings on stem discs. Ring boundaries, however, were not always distinct and sometimes they were even locally absent as in S. alba (Table 2; Fig. 3). Indistinct ring boundaries in C. tagal and B. gymnorrhiza (Table 2; Fig. 3) hindered ring counting, as did failed pinning of the cambium due to the thick bark in H. littoralis. Parenchyma bands, the most striking anatomical features that most likely indicate markers for growth-ring boundaries in mangrove species, were, however, observed in $H$. littoralis as well as in C. tagal, L. racemosa and X. granatum (Table 2). $L$. racemosa showed distinct growth rings, as did $X$. granatum under the two different flooding conditions (Table 2; Fig. 3). X. granatum had formed two growth layers during the 1-year study period in four out of six trees; the other two trees had formed one and three rings. Only in L. racemosa annual ring formation could be suggested from the one ring that was formed during the 1-year experimental period (May 2005-June 2006).

Annual radial increments, based on the pinnings in May 2005 and felling in June 2006, differed significantly between species ( $F=5.91, p<0.01$, one-way ANOVA) with $S$. alba at study site 3 (Fig. 1) recording the highest increment of the six species and $X$. granatum recording high growth rates, irrespective of the study site (Table 1). C. tagal (site 4) and B. gymnorrhiza trees growing at site 3 (Fig. 1) had the lowest radial growth. Trees growing in study sites with low maximum soil water salinity values, coinciding with low salinity ranges experienced over the year and low inundation class, registered relatively high radial increments. Lower growth rates were found for trees growing under higher inundation class, associated with more extreme soil water salinity at least during one period of the year (Table 1). S. alba on the contrary showed a lower radial increment when maximum salinity and salinity range were lower (Table 1). This was most probably due to the insect infestation (Salagena discata, Lepidoptera) the $S$. alba trees were suffering from at site 1 , but not at site 3 (Fig. 1).

\section{Discussion}

In contrast to species with terminal parenchyma bands, clearly demarcating growth rings (Gourlay 1995; Heinrich and Banks 2006; Trouet et al. 2006), Rhizophora exhibits no abrupt changes in wood anatomy that could indicate growth rings. Instead, the wood of Rhizophora shows gradual changes in vessel density that most likely reflect contemporary changes in soil water salinity caused by the variation in fresh water supply (Verheyden et al. 2004b). However, climate did have an effect on the clarity of the growth rings in Rhizophora (Fig. 2). While growth rings were extremely indistinct under the equatorial climate of south-western Sri Lanka, they were much more distinct in 
Table 2 Wood anatomical description of the growth rings of seven Kenyan mangrove species indicating the variables that change in gradual or abrupt way leading to indistinct or distinct ring boundaries, respectively (Fig. 3) as defined by Wheeler et al. (1989)

\begin{tabular}{lll}
\hline Species (family) & Variable & Type of boundary \\
\hline $\begin{array}{l}\text { Sonneratia alba (Lythraceae) } \\
\text { Heritiera littoralis (Malvaceae) }\end{array}$ & Vessel density and/or fibre wall thickness (discontinuously) & Indistinct-absent \\
Ceriops tagal (Rhizophoraceae) & Axial parenchyma band of 2-4 cells & Distinct \\
& Vessel density axial parenchyma band of 2-3 cells & Indistinct \\
Bruguiera gymnorrhiza (Rhizophoraceae) & (only occasionally) & Indistinct \\
Xylocarpus granatum (Meliaceae) & Axial parenchyma band of 1-5 cells & Distinct \\
Lumnitzera racemosa (Combretaceae) & Vessel density axial parenchyma band of 1-3 cells fibre & Distinct \\
Rhizophora mucronata (Rhizophoraceae) & cell wall thickness vessel diameter (minor difference) & Indistinct*
\end{tabular}

Nomenclature is according to the Angiosperm Phylogeny Group (Stevens 2001 onwards)

* Data from Verheyden et al. (2004b)

Fig. 3 Wood anatomy of six Kenyan mangrove species showing distinct ring boundaries for Heritiera littoralis, Xylocarpus granatum and Lumnitzera racemosa and indistinct or no ring boundaries for Sonneratia alba, Ceriops tagal and Bruguiera

gymnorrhiza. Arrowheads mark distinct (right) and indistinct (left) ring boundaries. Scale bars are $500 \mu \mathrm{m}$
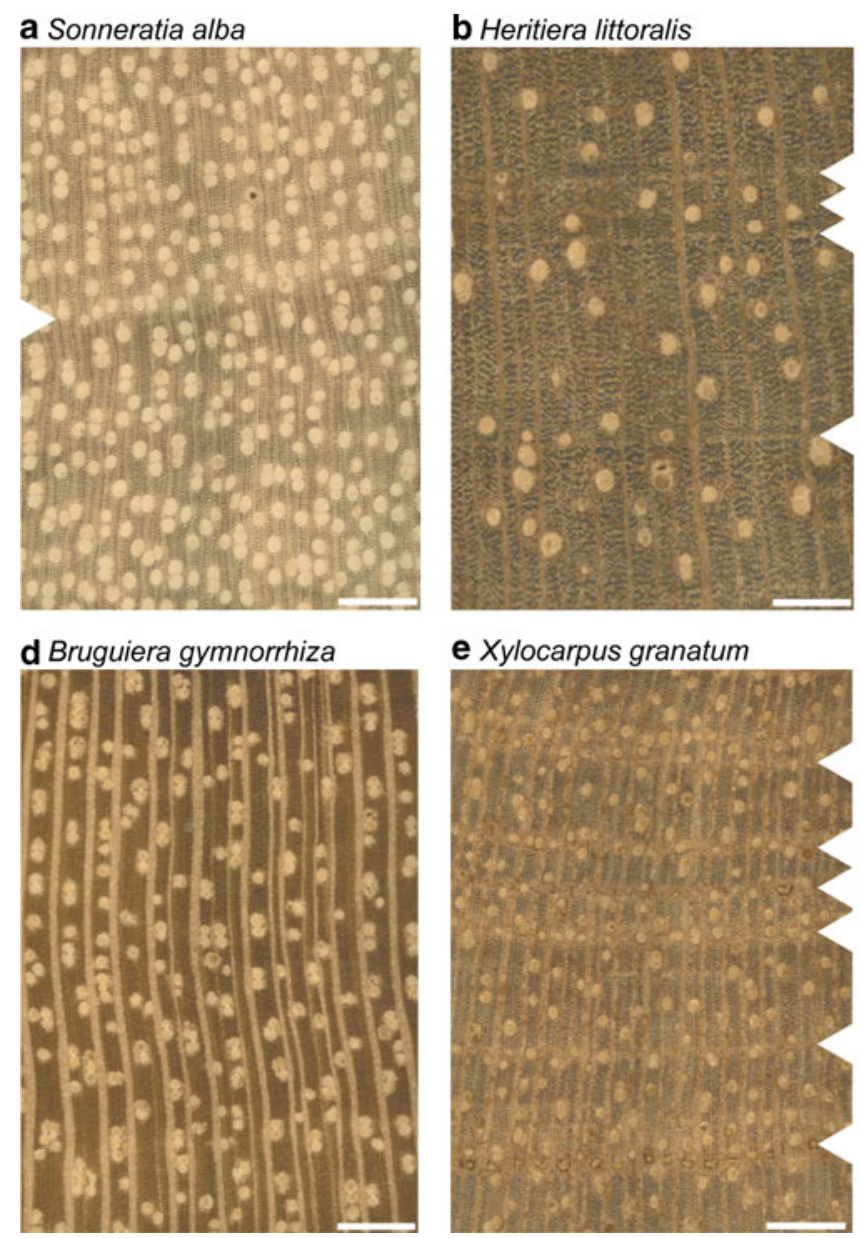

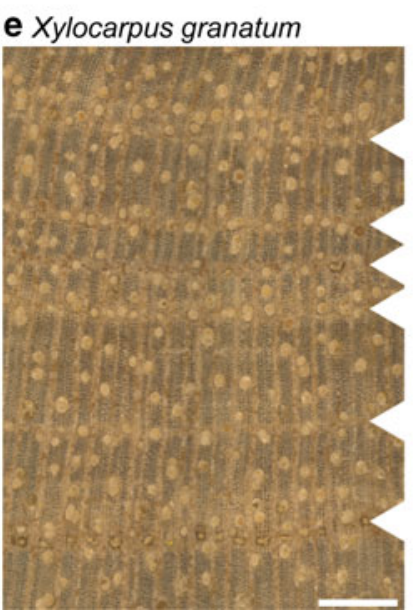

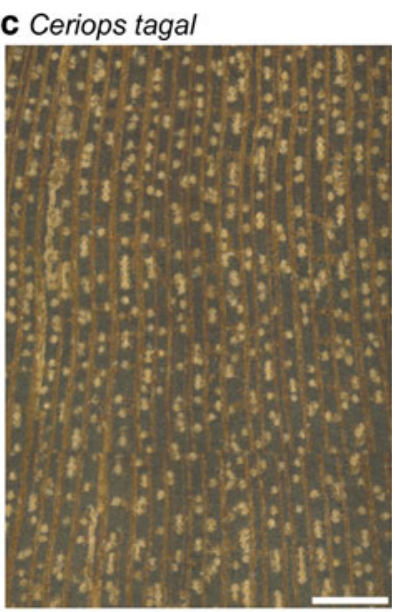

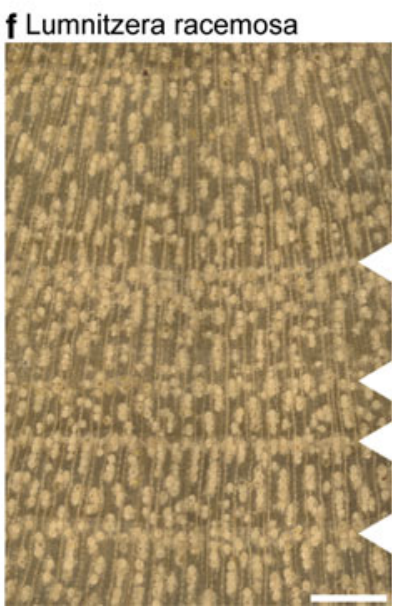

the Kenyan monsoonal climate (Verheyden et al. 2004a, b, 2005) and almost distinct in Rhizophora trees growing under the warm desert climate of Djibouti (Fig. 2). The local environmental conditions, affected by a period of drought, are thus critical for growth ring formation in
Rhizophora. Although Djibouti has an ever-dry climate, rainfall variations do occur on the field, causing fluctuations in soil water salinity and hence growth rings.

Consequently, the presence of a seasonal climate is no guarantee for growth rings in mangrove although for 
Rhizophora this does count. The mangrove trees of both Kenya and the Sunderbans in Bangladesh are subjected to a climate characterized by dry and rainy seasons, but only the latter shows growth rings (Fig. 3a) (Chowdhury et al. 2008). This is explained by the dissimilar effect of the climate on the locally experienced conditions. The Sonneratia trees in Gazi Bay, Kenya, are almost permanently flooded by seawater. The increased evaporation or input of fresh water during the dry and the rainy season, respectively, can therefor cause only minor changes in salinity (inundation class I, Table 1). These do not seem to be enough to create distinct growth-ring boundaries by a gradually changing vessel density (Table 2; Fig. 3a). The Bangladeshi mangroves, in contrast, experience a much bigger drop in salinity during the rainy season due to the network of streams and rivers criss-crossing the forest (Hoque et al. 2006; Wahid et al. 2007). The moderating effect of permanent flooding can also be observed within the mangrove forest of Gazi Bay when different sites are compared. The $R$. mucronata trees growing close to site 1 (Fig. 1) are protected from frequent flooding by a dune in comparison with the trees of site 3 (Fig. 1). This results in a larger salinity fluctuation between seasons (Table 1) causing a bigger difference in vessel density and resulting in more distinct growth rings (Fig. 2f, g).

Next to exogenous factors, the genetically determined wood anatomy affects the distinctness and expression of growth-ring boundaries (Worbes 1999). Species in which gradual changes in wood anatomy, such as vessel density, occur as indicator for seasonal changes need a minimum growth rate to guarantee that these changes in vessel characteristics can be detected. For R. mucronata in Gazi the minimum growth rate to be able to detect growth-ring boundaries was $0.5 \mathrm{~mm} /$ year (Verheyden et al. 2004a, $2004 b)$. Only when the cambium is active enough to form a considerable amount of wood with a different anatomy depending on prevailing wet or dry conditions a growthring boundary will be visible. When cambial activity is generally low as in $C$. tagal and B gymnorrhiza (Table 1), no variation in wood anatomy can be detected as small zones of high and low vessel density merge resulting in obscured growth rings (Table 2; Fig. 3c, d). In both $L$. racemosa and $X$. granatum, showing distinct growth rings, parenchyma bands mark the ring boundaries (Table 2; Fig. 3e, f). Therefore, the formation of distinct rings was not hindered by the rather low growth rate of L. racemosa (Table 1$)$. The presence of growth rings in $X$. granatum, growing in sites with only small variation in salinity values (salinity range $11 \%$, Table 1 ), indicated that this was sufficient to cause the formation of a parenchyma band. The less pronounced second dry season was probably even the source of the second ring boundary formed during the 1-year study period in all but one tree. The cause for missing second ring could be a slightly different microenvironment, as the sandy soil in site 2 , where the tree was growing, is susceptible for small variations in fresh water supply. The observation of three rings in another tree illustrates that parenchyma bands can also be caused by other factors [e.g. defoliation creating false rings (Heinrich and Banks, 2006)].

A tenfold range in annual radial increment has been observed in the six mangrove species studied (Table 1). Compared with the radial growth rate of B. gymnorrhiza $(1.2-3 \mathrm{~cm} /$ year) and $S$. alba $(1.5-5 \mathrm{~cm} /$ year) in Micronesia (Krauss et al. 2007), the annual growth of our trees from Kenya is very low, which emphasizes the diversity between mangrove forests. The high rainfall in the Micronesian study sites compared with the rainfall in the areas of the present study is most probably the cause of the faster growth, although nutrient effects cannot be excluded (Lin and Sternberg 1992; Feller et al. 2003; Lovelock et al. 2004; Krauss et al. 2007, 2008). Since mean radial increment was calculated from only six trees in the maximum, coming from two different sites, the result might not be relevant for the species. Therefore, site- and tree-specific effects have to be taken into account when comparing these data with other growth rhythm information.

We can conclude that due to the global distribution of mangroves across climatic regions (Duke 1995; Duke et al. 2002) and their local distribution across the intertidal zone, the presence of growth rings is dependent on climatic conditions that result in a variation of soil water salinity over the year (Fig. 4, climate seasonality and periodic extreme environmental conditions). In addition, species with ring boundaries characterized by parenchyma bands are more likely to form distinct rings (Table 2; Fig. 4). In species with a gradual change in vessel density demarcating tree rings, slow growth leads to merging of rings (Fig. 4). Radial increment varied but was limited by a large soil water salinity fluctuation over the year, which is related to a high annual maximum salinity and a low inundation frequency. For tree rings to be formed, a growth rate above $0.3 \mathrm{~mm} /$ year and a strong seasonal signal in fresh water input and soil water salinity, not obscured by tidal inundation, should occur (Fig. 4, dampening local conditions). For the three studied species showing distinct growth rings, more research is needed to clarify the annual nature of the observed rings. The study period should include more than 1 year and trees of different sizes should be included in order to be able to assess ontogenetic effects on anatomy and distinctness of growth rings (Brienen and Zuidema 2005; Heinrich and Banks 2005; Esper et al. 2008). For now, we advice that tree rings in mangroves should be handled on a caseby-case basis and should only be used for age or growth 


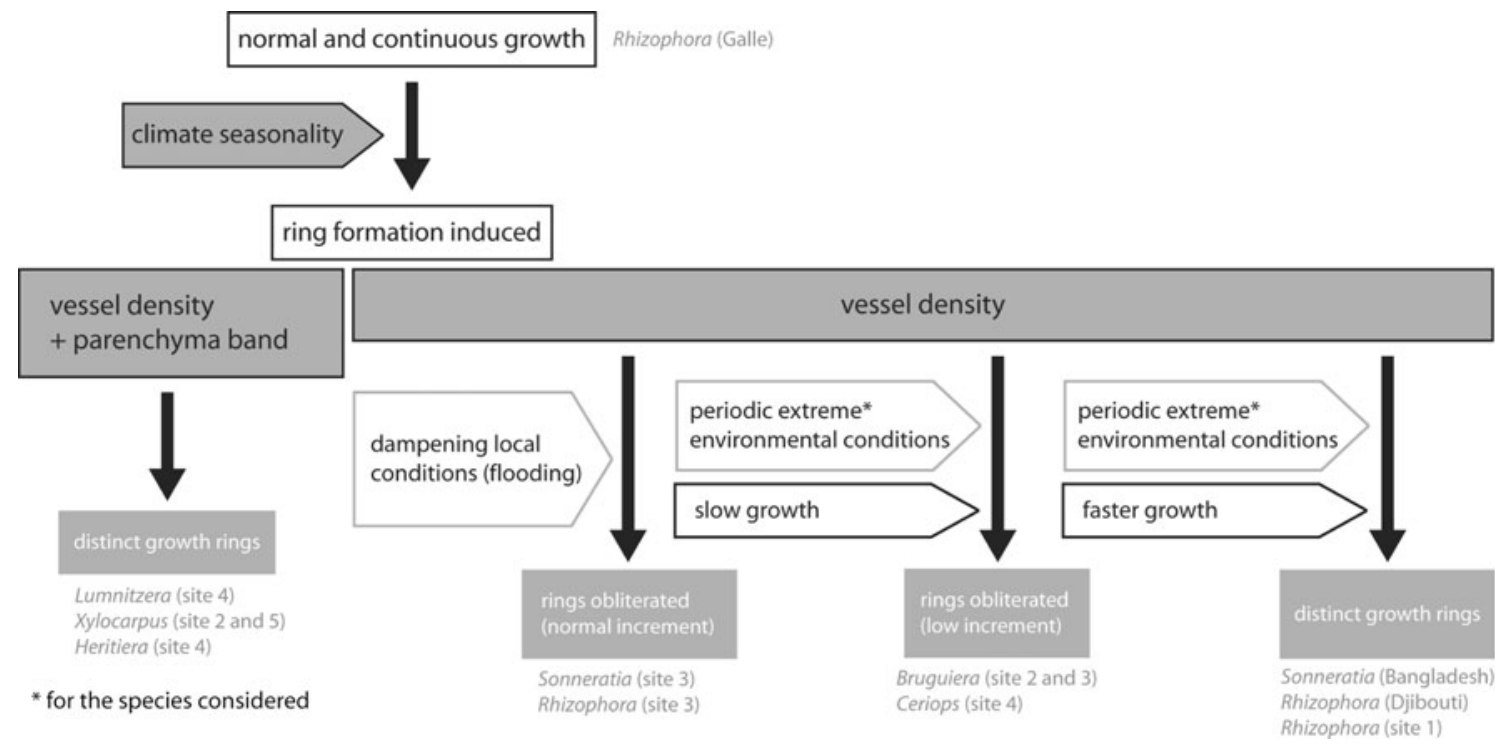

Fig. 4 Overview of the observed ring clarity for all mangrove species studied in function of the climate they grow in or the location in the mangrove forest (between brackets) as mentioned in Figs. 1 and 2. The climatic factors (grey arrows), the environmental factors (white arrows) and the species-specific factors (grey boxes with black text) at

rate estimations after at least a preliminary investigation of the annual nature of the wood anatomically definable zones that can be seen in the wood.

Acknowledgments We thank James Gitundu Kairo of the Kenyan Marine and Fisheries Research Institute (KMFRI) for the logistic help during field expeditions, Hamisi Ali Kirauni for the help during the field work and Anouk Verheyden for the well collected samples deposited in the Tervuren xylarium. We are grateful to two anonymous reviewers for their critical comments on an earlier version of the manuscript. N.S. is supported by the National Fund for Scientific Research (FWO, Belgium) but during set up of this study she was supported by the Institute for the Promotion of Innovation through Science and Technology in Flanders (IWT-Vlaanderen) as is E.M.R.R. J.A.O. is supported by the Flemish Interuniversity Council (VLIR). Additional support came from the AFRODENDRO project of the Royal Museum for Central Africa (RMCA), Tervuren. This research was further sponsored by travel grants from the FWO, the Schure-BeijerinckPopping Fonds (Koninklijke Nederlandse Akademie van Wetenschappen, Nederland) and the Flemish Interuniversity Council (VLIR).

\section{References}

Amobi CC (1974) Periodicity of wood formation in twigs of some Tropical trees in Nigeria. Ann Bot 38:931-936

Aziz I, Khan MA (2001) Effect of seawater on the growth, ion content and water potential of Rhizophora mucronata Lam. J Plant Res 114:369-373

Baker RT (1915) The Australian "grey mangrove", (Avicennia officinalis, Linn.). J Proc Roy Soc NS Wales 49:257-281

Berlage HP (1931) Over het verband tusschen de dikte der jaarringen van djatiboomen (Tectona grandis L.f.) en den regenval op Java. Tectona 24:939-953 the base of the presence of absence of distinct growth rings are indicated. Sonneratia trees from study site 1 (Fig. 1) have not been integrated in the figure as they are suffering from an insect infestation. Sonneratia trees from Chowdhury et al. (2008), however, were

Brienen RJW, Zuidema PA (2005) Relating tree growth to rainfall in Bolivian rain forests: a test for six species using tree ring analysis. Oecologia 146:1-12

Chowdhury MQ, Schmitz N, Verheyden A, Sass-Klaassen U, Koedam N, Beeckman H (2008) Nature and periodicity of growth rings in two Bangladeshi mangrove species. IAWA J 29:265-276

Coster C (1927) Zur Anatomie und Physiologie der Zuwachszonen und Jahresringbildung in den Tropen I. Annales Jardim Botanica Buitenzorg 37:49-161

Coster C (1928) Zur Anatomie und Physiologie der Zuwachszonen und Jahresringbildung in den Tropen II. Annales Jardim Botanica Buitenzorg 38:1-114

Duke NC (1995) Genetic diversity, distributional barriers and rafting Continents-more thoughts on the evolution of mangroves. Hydrobiologia 295:167-181

Duke NC, Bunt JS, Williams WT (1981) Mangrove litter fall in North-Eastern Australia. I. Annual totals by component in selected species. Aust J Bot 29:547-553

Duke NC, Lo EYY, Sun M (2002) Global distribution and genetic discontinuities of mangroves-emerging patterns in the evolution of Rhizophora. Trees Struct Funct 16:65-79

Dunisch O, Bauch J, Gasparotto L (2002) Formation of increment zones and intraannual growth dynamics in the xylem of Swietenia macrophylla, Carapa guianensis, and Cedrela odorata (Meliaceae). IAWA J 23:101-119

EP UN (2001) Eastern African Database and Atlas Project (EAF/14). The Eastern African Coastal Resources Atlas. United Nations Environmental Program, Kenya

Esper J, Niederer R, Bebi P, Frank D (2008) Climate signal age effects-evidence from young and old trees in the Swiss Engadin. For Ecol Manag 255:3783-3789

Feller IC, Whigham DF, McKee KL, Lovelock CE (2003) Nitrogen limitation of growth and nutrient dynamics in a disturbed mangrove forest, Indian River Lagoon, Florida. Oecologia 134:405-414 
Fichtler E, Clark DA, Worbes M (2003) Age and long-term growth of trees in an old-growth tropical rain forest, based on analyses of tree rings and ${ }^{14} \mathrm{C}$. Biotropica 35:306-317

Fichtler E, Trouet V, Beeckman H, Coppin P, Worbes M (2004) Climatic signals in tree rings of Burkea africana and Pterocarpus angolensis from semiarid forests in Namibia. Trees Struct Funct 18:442-451

Field CD (1998) Rehabilitation of mangrove ecosystems: an overview. Mar Pollut Bull 37:383-392

Geiger F (1915) Anatomische Untersuchungen über die Jahresringbildung von Tectona grandis. Jahrbuch für Wissenschaftliche Botanik 55:521-607

Gourlay ID (1995) The definition of seasonal growth zones in some African acacia species-a review. IAWA J 16:353-359

Hancock GJ, Murray AS, Brunskill GJ, Argent RM (2006) Ra isotopes in trees: their application to the estimation of heartwood growth rates and tree ages. Global Biogeochem Cycles 20. doi:10.1029/2005GB002641

Heinrich I, Banks JCB (2005) Dendroclimatological potential of the Australian red cedar. Aust J Bot 53:21-32

Heinrich I, Banks JCB (2006) Tree-ring anomalies in Toona ciliata. IAWA J 27:213-231

Hoque MA, Sarkar MSKA, Khan SAKU, Moral MAH, Khurram AKM (2006) Present Status of Salinity Rise in Sundarbans Area and its Effect on Sundari (Heritiera fomes) Species. Res J Agric Biol Sci 2:115-121

Iqbal M (1925) A.The meristem. Structure and behaviour of vascular cambium and the mechanism and control of cambial growth. In: Iqbal M The cambial derivates. Encyclopedia of plant anatomy

Jacoby GC (1989) Overview of tree-ring analysis in tropical regions. IAWA Bull 10:99-108

Kitheka JU (1997) Coastal tidally-driven circulation and the role of water exchange in the linkage between tropical coastal ecosystems. Estuar Coast Shelf Sci 45:177-187

Krauss KW, Doyle TW, Twilley RR, Rivera-Monroy VH, Sullivan JK (2006) Evaluating the relative contributions of hydroperiod and soil fertility on growth of south Florida mangroves. Hydrobiologia 569:311-324

Krauss KW, Keeland BD, Allen JA, Ewel KC, Johnson DJ (2007) Effects of season, rainfall, and hydrogeomorphic setting on mangrove tree growth in Micronesia. Biotropica 39:161-170

Krauss KW, Lovelock CE, Mc Kee KL, López-Hoffman L, Ewe SML, Sousa WP (2008) Environmental drivers in mangrove establishment and early development: a review. Aquat Bot $89: 105-127$

Lieth H, Berlekamp J, Fuest S, Riediger S (1999) CD 1-climate diagram World atlas. Backhuys Publishers, Leiden

Lin G, Sternberg LDL (1992) Effect of growth form, salinity, nutrient and sulfide on photosynthesis, carbon isotope discrimination and growth of Red Mangrove (Rhizophora mangle L.). Aust J Plant Physiol 19:509-517

Lovelock CE, Feller IC, Mckee KL, Engelbrecht BMJ, Ball MC (2004) The effect of nutrient enrichment on growth, photosynthesis and hydraulic conductance of dwarf mangroves in Panama. Funct Ecol 18:25-33

Manhas RK, Negi JDS, Kumar R, Chauhan PS (2006) Temporal assesment of growing stock, biomass and carbon stock of Indian forests. Clim Change 74:191-221

Marco HF (1935) Systematic anatomy of the woods of the Rhizophoraceae. Tropical Woods 4:1-20

Mariaux A (1967a) Les cernes dans les bois tropicaux africains: nature et périodicité. Revue Bois et Forêts des Tropiques 113:3-14

Mariaux A (1967b) Les cernes dans les bois tropicaux africains: nature et périodicité. Revue Bois et Forêts des Tropiques 114:23-37
Mariaux A (1969) La périodicité de formation des cernes dans le bois de Limba. Revue Bois et Forêts des Tropiques 128:39-54

Mariaux A (1981) Past effects in measuring age and annual growth in tropical trees. In: Bormann FH, Berlyn G (eds) Age and growth rate of tropical trees: New directions for research. Yale University Press, New Haven

Mattsson E, Ostwald M, Nissanka SP, Holmer B, Palm M (2009) Recovery and protection of coastal ecosystems after tsunami event and potential for participatory forestry CDM-examples from Sri Lanka. Ocean Coast Manage 52:1-9

Menezes M, Berger U, Worbes M (2003) Annual growth rings and long-term growth patterns of mangrove trees from the Bragança peninsula, North Brazil. Wetl Ecol Manag 11:233-242

Nabuurs GJ, Mohren GMJ (1995) Modelling analysis of potential carbon sequestration in selected forest types. Can J For Res 25:1157-1172

Neukermans G, Dahdouh-Guebas F, Kairo JG, Koedam N (2008) Mangrove Species and Stand Mapping in Gazi bay (Kenya) using Quickbird Satellite Imagery. Spatial Sci 53:75-86

Peel MC, Finlayson BL, Mc Mahon TA (2007) Updated world map of the Köppen-Geiger climate classification. Hydrol Earth Syst Sci Discuss 4:439-473

Rajkaran A, Adams JB (2008) The effect of sediment conditions on the growth rate of mangroves. S Afr J Bot 74:375-376

Rao RV, Sharma B, Chauhan L, Dayal R (1987) Reinvstigations of the wood anatomy of Duabanga and Sonneratia with particular reference to their systematic position. IAWA Bull n.s. 8:337-345

Robert EMR, Koedam N, Beeckman H, Schmitz N (2009a) A safe hydraulic architecture as wood anatomical explanation for the difference in distribution of the mangroves Avicennia and Rhizophora. Funct Ecol 23:649-657

Robert EMR, Schmitz N, Kirauni HA, Koedam N (2009b) Salinity fluctuations in the mangrove forest of Gazi Bay, Kenya: lessons to take for future research. Nature and Faune 24:89-95

Roig FA, Osornio JJJ, Diaz JV, Luckman B, Tiessen H, Medina A, Noellemeyer EJ (2005) Anatomy of growth rings at the Yucatán Peninsula. Dendrochronologia 22:187-193

Sass U, Killmann W, Eckstein D (1995) Wood formation in two species of Dipterocarpaceae in peninsular Malaysia. IAWA J 16:371-384

Schmitz N, Verheyden A, Kairo JG, Beeckman H, Koedam N (2007) Successive cambia development in Avicennia marina (Forssk.) Vierh. is not climatically driven in the seasonal climate at Gazi Bay, Kenya. Dendrochronologia 25:87-96

Schmitz N, Robert EMR, Verheyden A, Kairo JG, Beeckman H, Koedam N (2008) A patchy growth via successive and simultaneous cambia: key to success of the most widespread mangrove species Avicennia marina? Ann Bot 101:49-58

Schöngart J, Junk WJ, Piedade MFT, Hüttermann A, Worbes M (2004) Teleconnection between forest growth in the Amazonian floodplains and El Niño. Global Change Biol 10:683-693

Schöngart J, Piedade MFT, Wittmann F, Junk WJ, Worbes M (2005) Wood growth patterns of Macrolobium acaciifolium (Benth.) Benth. (Fabaceae) in Amazonian black-water and white-water floodplain forests. Oecologia 145:454-461

Schöngart J, Orthmann B, Hennenberg KJ, Porembski S, Worbes M (2006) Climate-growth relationships of tropical tree species in West Africa and their potential for climate reconstruction. Global Change Biol 12:1139-1150

Shiokura T (1989) A method to measure radial increment in tropical trees. IAWA Bull n.s. 10:147-154

Srivastava R, Suzuki M (2001) More fossil woods from the palaeogene of northern Kyushu, Japan. IAWA J 22:85-105

Stevens PF (2001 onwards) Angiosperm Phylogeny Website. Version 9. http://www.mobot.org/MOBOT/research/APweb/. Accessed June 2008 
Sun Q, Suzuki M (2000) Wood anatomy of mangrove plants in Iriomote Island of Japan: a comparison with mangrove plants from lower lattitudes. Acta Phytotax Geobot 51:37-55

Tomlinson PB (1994) The Botany of Mangroves. Cambridge University Press, Cambridge

Trouet V, Haneca K, Coppin P, Beeckman H (2001) Tree ring analysis of Brachystegia spiciformis and Isoberlinia tomentosa: evaluation of the enso-signal in the miombo woodland of eastern Africa. IAWA J 22:385-399

Trouet V, Coppin P, Beeckman H (2006) Annual growth ring patterns in Brachystegia spiciformis reveal influence of precipitation on tree growth. Biotropica 38:375-382

Van Vliet GJCM (1976) Wood anatomy of the Rhizophoraceae. Leiden Bot Ser 3:20-75

Verheyden A, Helle G, Schleser GH, Dehairs F, Beeckman H, Koedam N (2004a) Annual cyclicity in high-resolution stable carbon and oxygen isotope ratios in the wood of the mangrove tree Rhizophora mucronata. Plant Cell Environ 27:1525-1536

Verheyden A, Kairo JG, Beeckman H, Koedam N (2004b) Growth rings, growth ring formation and age determination in the mangrove Rhizophora mucronata. Ann Bot 94:59-66

Verheyden A, De Ridder F, Schmitz N, Beeckman H, Koedam N (2005) High-resolution time series of vessel density in Kenyan mangrove trees reveal a link with climate. New Phytol 167:425-435

Vieira S, Trumbore S, Camargo PB, Selhorst D, Chambers JQ, Higuchi N, Martinelli LA (2005) Slow growth rates of Amazonian trees: Consequences for carbon cycling. Proc Natl Acad Sci USA 102:18502-18507

Wahid SM, Babel MS, Bhuiyan AR (2007) Hydrologic monitoring and analysis in the Sundarbans mangrove ecosystem, Bangladesh. J Hydrol 332:381-395

Walter H, Breckle S-W (1999) Vegetation und Klimazonen. Grundriss der globalen Ökologie. Eugen Ulmer, Stuttgart
Wheeler EA, Baas P, Gasson PE (1989) IAWA list of microscopic features for hardwood identification. IAWA Bull n.s. $10: 219-332$

Worbes M (1985) Structural and other adaptations to long-term flooding by trees in Central Amazonia. Amazoniana 9:459-484

Worbes M (1990) Site and sample selection in tropical forests. In: Cook ER, Kairiuksis LA (eds) Methods of dendrochronology. Applications in the environmental sciences. Kluwer Academic Publishers, Dordrecht

Worbes M (1995) How to measure growth dynamics in tropical trees-a review. IAWA J 16:337-351

Worbes M (1997) The forest ecosystems of the floodplains. In: Junk WJ The Amazonian floodplains: ecology of a pulsing system. Ecological Studies 126.) Springer, Berlin

Worbes M (1999) Annual growth rings, rainfall-dependent growth and long-term growth patterns of tropical trees from the Caparo Forest Reserve in Venezuela. J Ecol 87:391-403

Worbes M, Junk WJ (1989) Dating tropical trees by means of 14C from bomb tests. Ecology 70:503-507

Worbes M, Klinge H, Revilla JD, Martius C (1992) On the dynamics, floristic subdivision and geographical distribution of várzea forests in Central Amazonia. J Veg Sci 3:553-564

Worbes A, Staschel R, Roloff A, Junk WJ (2003) Tree ring analysis reveals age structure, dynamics and wood production of a natural forest stand in Cameroon. For Ecol Manag 173:105-123

Yu K, Zhao J, Liu T, Wang P, Qian J, Chen T (2004) Alpha-cellulose $\delta 13 \mathrm{C}$ variation in mangrove tree rings correlates well with annual sea level trend between 1982 and 1999. Geophys Res Lett $31: 1-4$

Yu KF, Kamber BS, Lawrence MG, Greig A, Zhao JX (2007) Highprecision analysis on annual variations of heavy metals, lead isotopes and rare earth elements in mangrove tree rings by inductively coupled plasma mass spectrometry. Nucl Instrum Methods Phys Res B Beam Interact Mater Atoms 255:399-408 